\title{
ПЛАСТИЧНОСТЬ И СТАБИЛЬНОСТЬ ЯРОВОГО ОВСА ПО УРОЖАЙНОСТИ И МАССЕ 1000 ЗЕРЕН
}

\author{
L.P. Baykalova, Yu.I. Serebrennikov
}

\section{THE PLASTICITY AND STABILITY OF SPRING OATS IN YIELD AND THE MASS OF AND 1000 GRAINS}

Байкалова Лариса Петровна - д-р с.-х. наук, проф. каф. растениеводства, селекции и семеноводства Красноярского государственного аграрного университета, г. Красноярск.

E-mail: kos.69@mail.ru

Серебренников Юрий Иванович - канд. с.-х. наук, зав. Уярским государственным сортоиспытательным участком (ГСУ) филиала ФГБУ «Госсорткомиссия» по Красноярскому краю, Республике Хакасия и Республике Тыва, Красноярский край, Емельяновский р-н, п. Емельяново.

E-mail: ivanoff.yurser2011@yandex.ru

В статье представлены результаты исследований 2017-2019 ге., проведенных на Уярском государственном сортоиспытательном участке, расположенном в лесостепной зоне Красноярского края. Цель работы - выявление наиболее пластичных сортов, а также сортов с наибольшей стабильностью, ярового овса по урожайности зерна и массе 1000 зерен при их возделывании по интенсивной технологии. Задачи: вычислить экологическую пластичность и стабильность сортов ярового овса по урожайности и массе 1000 зерен. Методы исследования: опыты и наблюдения проводились в соответствии с методикой государственного сортоиспытания. Закладывались опыты в четырехкратной повторности,

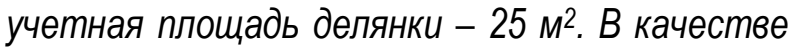
объектов исследования выступили сорта пленчатого и голозерного овса: Тубинский, Аргумент, Голец, Саян, Сиг и Урал-2. За стандарт брали сорт Тубинский. Показатели экологической пластичности и стабильности определяли по методам S.A. Eberhart et W.A. Russell, Rossielle et Hamblin, Г.T. Селянинова c применением компьютерной программы «Excel». Анализ урожайных данных и массы 1000 зерен овса показал, что в один год из трех, то есть в 33,3 \% случаев, индекс условий среды был отрицательным. Урожайность
Baykalova Larisa Petrovna - Dr. Agr. Sci., Prof., Chair of Plant Growing, Selection and Seed Farming, Krasnoyarsk State Agrarian University, Krasnoyarsk.

E-mail: kos.69@mail.ru

Serebrennikov Yury Ivanovich - Cand. Agr. Sci., Head, Uyar State Variety Trials Site, FSBI 'Gossortkomissiya' Branch for Krasnoyarsk Region, the Republics of Khakassia and Tyva, Krasnoyarsk Region, Emelyanovo District, S. Yemelyanovo.

E-mail: ivanoff.yurser2011@yandex.ru

и масса 1000 зерен возрастали пропорционально росту индексов условий среды от положительных значений $k$ отрицательным. Лучший индекс условий среды по урожайности был в 2017 г., по массе 1000 зерен - в 2019 г. По урожайности большую стрессоустойчивость показал сорт Саян 0,14, по индексу экологической пластичности (ИЭП) выделились Тубинский, Аргумент и Саян. ИЭП этих сортов был больше единицы, что свидетельствует о пластичности сорта и высокой ценности при его воздельвании. Незначительное варьирование урожайности отмечено у сорта Сиг 1,6 \%, значительное - у сорта Урал-2 - $24 \%$, у сортов Тубинский, Аргумент и Саян варьирование урожайности имело среднюю степень 16,4-18,8 \%. Большую отзывчивость на изменение условий выращивания показали сорта Тубинский и Аргумент, коэфрфициент линейной регрессии (bi) составлял 3,2 и 2,3 coomветственно. По урожайности наибольшую пластичность проявили Аргумент, Саян, Сиг, а стабильность - Аргумент, Голец и Саян. По массе 1000 зерен сорта Аргумент, Голец, Саян являлись самыми пластичными и стабильHЬIMU.

Ключевые слова: экологическая пластичность, стабильность, урожайность, масса 1000 зерен, овес яровой. 
The results of the researches of 2017-2019 conducted at Uyarsky State Variety Trials Site 10cated in a forest-steppe zone of Krasnoyarsk Region were presented in the study. The research purpose was the identification of the most plastic varieties, and also the varieties with the greatest stability, spring oats on the productivity of grain and mass of 1000 grains at their cultivation using intensive technology. The tasks were to calculate ecological plasticity and stability of varieties of spring oats on the productivity and mass of 1000 grains. The research methods were the experiments and observations made according to the technique of the state variety trial. The experiments were made in quadruple frequency, the registration area of an allotment being 25 sq.m. The varieties of filmy and hull-less oats acted as the objects of the research: Tubinsky, Argument, Golets, Sayan, Sig and Ural2. The variety Tubinsky was taken as the standard. The indicators of ecological plasticity and stability were determined with the help of S.A. Eberhart et W.A. Russell, Rossielle et Hamblin method and that of G.T. Selyaninova with application of the computer 'Excel' program. The analysis of yield data and the mass of 1000 grains of oats showed that in one year from three, i.e. in $33.3 \%$ of the cases, the index of environment conditions had been negative. The productivity and mass of 1000 grains increased in the proportion to the growth of the indexes of environment conditions from positive values to negative. The best index of environment conditions on productivity was in 2017, on the mass of 1000 grains - in 2019. On yield greater stress resistance was shown by the variety Sayan 0.14 , on the index of ecological plasticity (IEP) were allocated Tubinsky, Argument and Sayan. IEP of these varieties was more than one testifying to the plasticity of the variety and high value at its cultivation. Insignificant variation of the productivity was noted in the variety Sig - $1.6 \%$, considerable - in the variety Urals-2 - $24 \%$, in the varieties Tubinsky, Argument and Sayan the variation of productivity had average degree - 16.4-18.8\%. Great reaction on the change of cultivation conditions was shown by the varieties Tubinsky and Argument, the coefficient of linear regression (bi) made 3.2 and 2.3 respectively. On the productivity the greatest plasticity was shown by Argument, Sayan, Sig and stability - by Argument, Golets and Sayan. On the mass of 1000 grains of the varieties Argument, Golets, Sayan were the most plastic and stable.
Keywords: ecological plasticity, stability, yield, weight of 1000 grains, spring oats.

Введение. Знание потенциала адаптивности сортов необходимо для правильного их размещения во всех почвенно-климатических зонах. Для его оценки используются параметры экологической пластичности и стабильности [1]. По A.D. Bradshaw, пластичность - способность генотипа изменять величину признаков в разных условиях выращивания, а стабильность - отсутствие пластичности [2].

По утверждению Д.Н. Прянишникова и И.В. Якушкина [3], овес - не культура сухих районов. Исследованиями Л.П. Байкаловой, О.А. Долговой [4] установлено, что в Красноярском крае максимальная урожайность овса формируется в лесостепи Причулымья. В связи с этим ОН В районах с большим недостатком летних осадков заменяется ячменем. Кроме того, вегетационный период у овса длиннее, чем у ячменя. Это является причиной того, что его северные границы располагаются южнее ячменных. С учетом вышесказанного, зная пластичность и стабильность сорта, можно отодвинуть границы распространения как сорта, так и культуры в целом. Для этого надо учитывать климатические условия в регионе, в котором предполагается внедрение сорта (культуры). Например, в регионе с недостатком летних осадков можно начать выращивать сорт, способный давать в указанных условиях не менее высокие урожаи, чем в регионе с достаточным их количеством.

Цель исследования. Оценить способность современных сортов овса давать одинаково высокие урожаи и массу 1000 зерен в условиях интенсивного земледелия в лесостепи Красноярского края в различных метеоусловиях.

Задачи: вычислить экологическую пластичность сортов овса по урожайности зерна и массе 1000 зерен; вычислить стабильность сортов овса по урожайности зерна и массе 1000 зерен.

Объекты и методы исследования. Полевые исследования проводились на полях конкурсного сортоиспытания Уярского государственного сортоиспытательного участка в 20172019 гг. в Красноярской лесостепи Красноярского края - в соответствии с методикой госсортоиспытания [5]. Почва - выщелоченный чернозем. Предшественник - пшеница яровая. Опыты закладывались в 4-кратной повторности с рендомизацией в пределах каждой из двух групп. 
Учетная площадь каждой делянки - 25 м². Способ посева - рядовой. Коэфффициент высева 5,0 млн всх. зерен/га. Обработка почвы осуществлялась в соответствии с агротехническими правилами, принятыми для данной почвенноклиматической зоны. Вносились удобрения: куриный помет (60 т/га), N (44 т/га), $\mathrm{P}_{2} \mathrm{O}_{5}$ (52 т/га). Осуществлялось предпосевное протравливание семян, обработка посевов всех сельскохозяйственных культур инсектицидами и фунгицидами. В данной работе было задействовано 6 сортов ярового овса преимущественно красноярской селекции. Овес подразделяется на 2 группы: пленчатый (5 сортов) и голозерный (1 сорт Голец).

Расчет коэфффициента линейной регрессии (экологической пластичности) (bi), меры стабильности (s²d), индекса условий среды (lj) осуществлялся по методике S.A. Eberhartet, W.A. Russell [6], стрессоустойчивость (У2-У1) по методике Rossielle et Hamblin [7]. Индекс эко- логической пластичности (ИЭП) и индекс стабильности (L') определялись по методике А.A. Грязнова (2000) [8]. Показатель уровня стабильности сорта (ПУСС) определялся по методике Э.Д. Неттевича, А.И. Моргунова, М.И. Максименко (1985) [9], коэфффициент вариации (V) - по методике Б.А. Доспехова (1985) [10], а размах урожайности (d) - по В.А. Зыкину (1984) [11]. Гидротермический коэфффициент (ГТК) рассчитывался по Г.Т. Селянинову [12]. Расчеты выполнены с помощью компьютерной программы «Excel» из офисного пакета программ MicrosoftOffice методом введения в соответствующие ячейки формул, используемых для расчета данных параметров.

Метеоусловия лет испытания отличались друг от друга. Самой прохладной декадой была 2-я декада мая $\left(7,5^{\circ} \mathrm{C}\right)$, а самой теплой - 3-я декада июня $\left(21,4^{\circ} \mathrm{C}\right)$ (рис. 1).

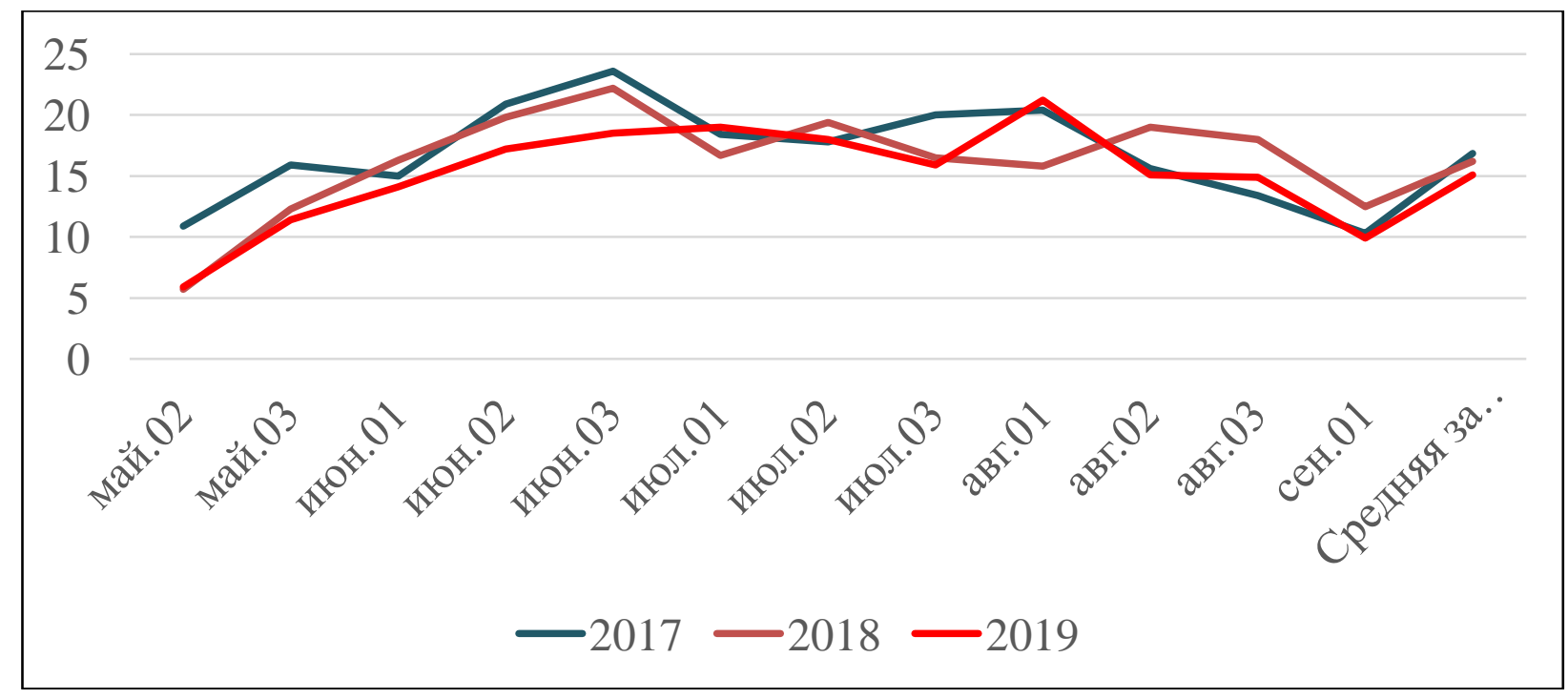

Puс. 1. Подекадный ход температур вегетационного периода на Уярском ГСУ в 2017-2019 г2., ${ }^{\circ} \mathrm{C}$

Осадков меньше всего было в 1-й декаде июня (4,4 мм), а больше всего - во 2-й декаде августа (40,1 мм) (рис. 2).

Гидротермический коэфффициент (ГТК) был наименьшим в 1-й декаде июня $(0,3)$, а наибольшим - во 2-й декаде августа (2,5) (рис. 3).

Засушливые условия сложились в 2018 г., когда осадков не было на протяжении 33 дней - с 17 июня по 19 июля (если судить по внешнему виду растений). Хотя на самом деле было 2 сухих периода - 17 и 13 дней. Осадки 4 и 6 июля (4,0 и 6,0 мм соответственно) фактически не принесли улучшения ситуации, то есть растения их просто не заметили. Кроме июня-июля 2017 г. засушливые условия отмечались в августе 2018 г. и августе 2019 г.

Индекс условий среды по годам был различным (рис. 4). 


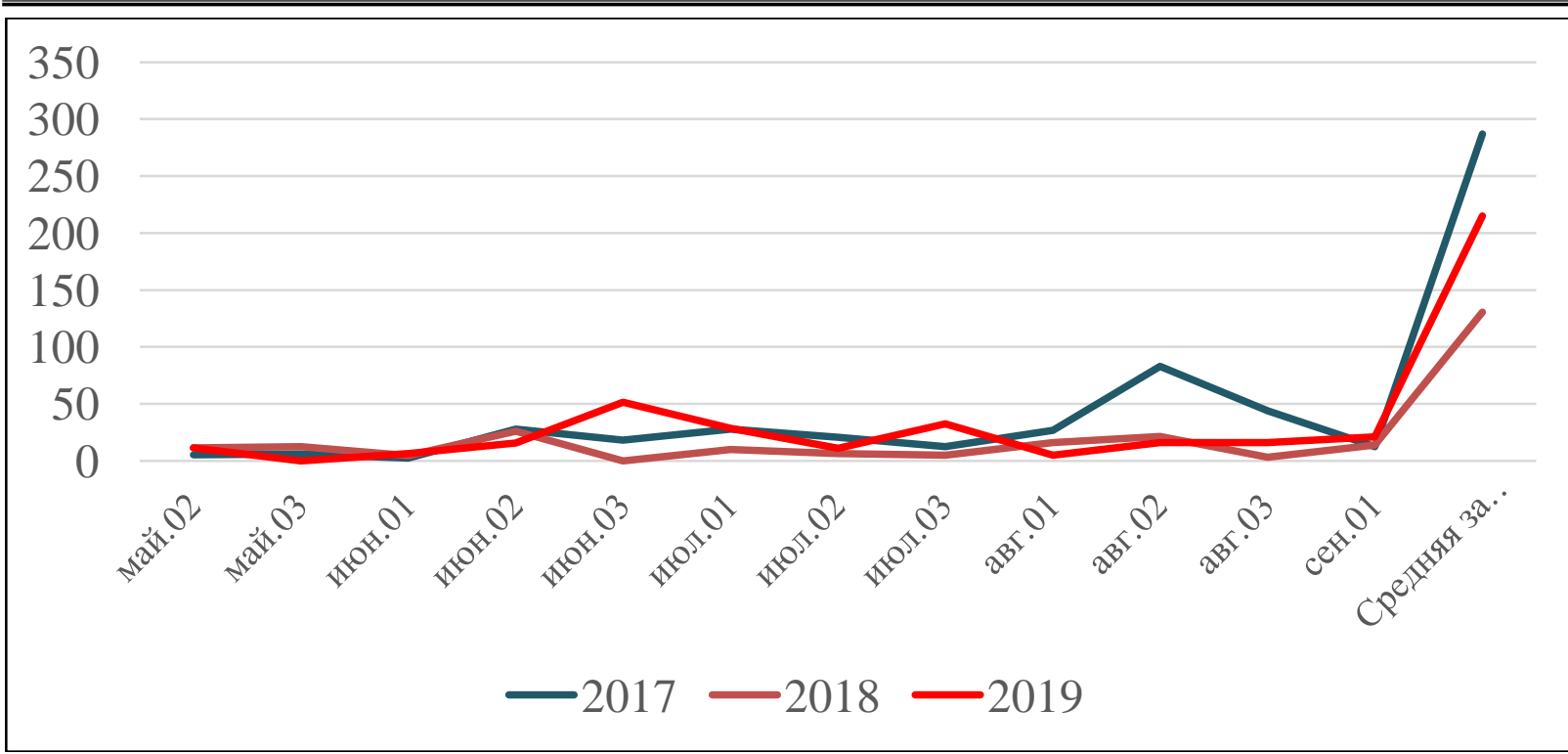

Puc. 2. Сумма осадков по декадам вегетационного периода на Уярском ГСУ в 2017-2019 г2., мм

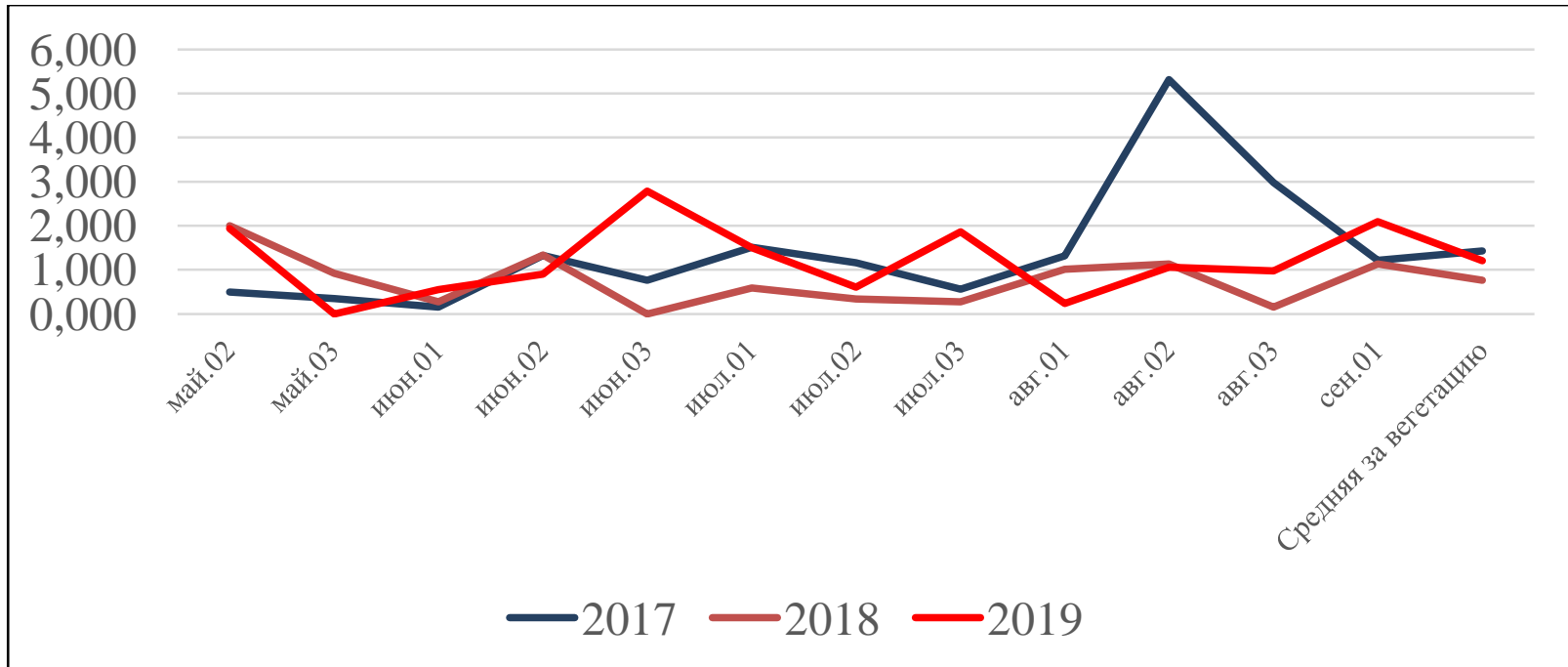

Puс. 3. Гидротермический коэффрициент вегетационного периода на Уярском ГСУ в 2017-2019 г2.

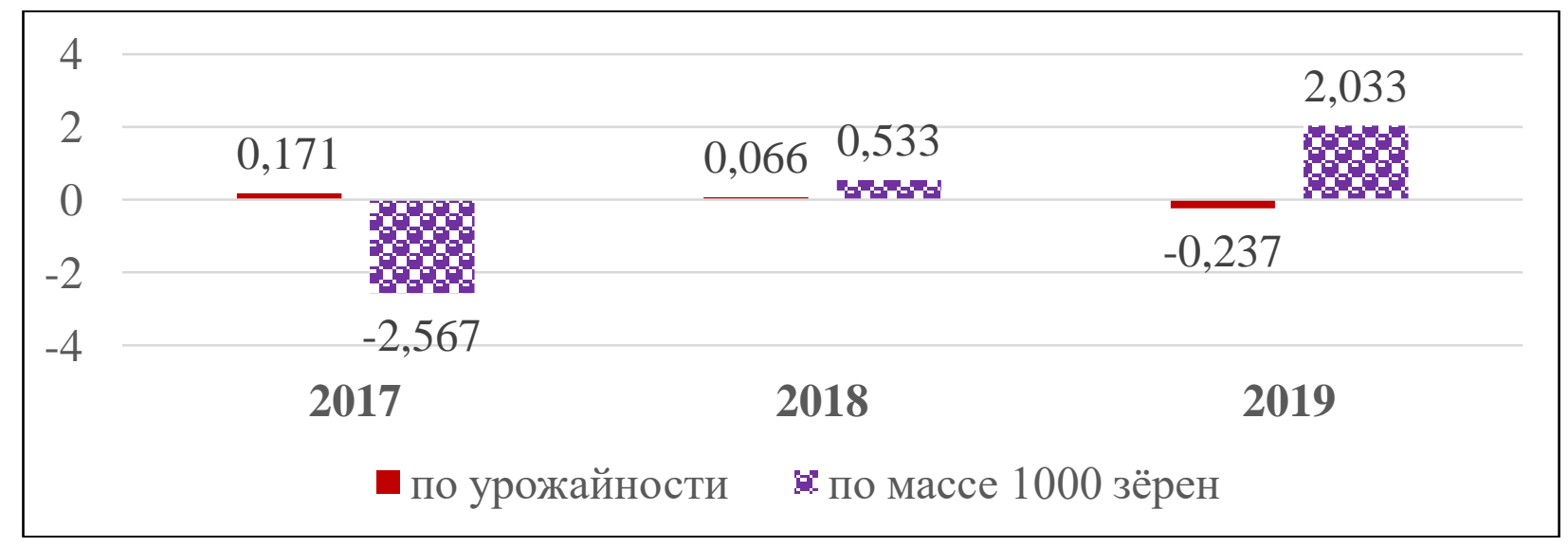

Puc. 4. Индекс условий среды для урожайности и массы 1000 зерен овса 
По урожайности У1 соответствовал 2017 г., У2 - 2019 г. По массе 1000 зерен сложилась обратная ситуация: У1 соответствовал 2019 г., У2 - 2017 г. При этом погодные условия лет исследований в целом соответствовали требованиям биологии исследуемой культуры.

Результаты исследования и их обсуждение. Наибольшая урожайность в среднем за годы исследований отмечена у сортов Тубин- ский, Аргумент и Саян. У этих же сортов среднемноголетняя урожайность в контрастные годы также выше, чем у остальных исследуемых сортов. При этом стоит отметить тот факт, что в контрастные годы урожайность больше среднемноголетней у сортов Саян, Сиг и особенно Урал 2. У последнего разница составляет 0,38 т/га (табл. 1).

Урожайность сортов овса ярового, т/га

Таблица 1

\begin{tabular}{|l|c|c|c|c|c|}
\hline \multicolumn{1}{|c|}{ Сорт } & 2017 & 2018 & 2019 & Средняя & (У1+У2)/2 \\
\hline Тубинский (станд.) & 4,26 & 4,32 & 3,03 & 3,87 & 3,65 \\
\hline Аргумент & 3,88 & 4,43 & 3,18 & 3,83 & 3,53 \\
\hline Голец & 2,50 & 3,28 & 2,41 & 2,73 & 2,46 \\
\hline Саян & 3,62 & 3,13 & 3,76 & 3,50 & 3,69 \\
\hline Сиг & 3,40 & 3,30 & 3,39 & 3,36 & 3,40 \\
\hline Урал 2 & 3,66 & 2,23 & 3,10 & 3,00 & 3,38 \\
\hline НСР $_{05}$ А & & & & 0,19 & \\
\hline НСР $_{5 \text { в }}$ & & & & 0,14 & \\
\hline НСР $_{5 \text { АхВ }}$ & & & & 0,33 & \\
\hline
\end{tabular}

Максимальная масса 1000 зерен формировалась у сортов Аргумент, Урал 2 и Саян; у них же она была больше и в контрастные годы ((У1+У2)/2) (табл. 2). У сортов Тубинский, Голец и Саян данный параметр наибольшим был в контрастные годы в сравнении со средней за годы исследований.

Масса 1000 зерен сортов овса ярового, г

\begin{tabular}{|l|c|c|c|c|c|}
\hline \multicolumn{1}{|c|}{ Сорт } & 2017 & 2018 & 2019 & Средняя & $(\mathrm{Y} 1+\mathrm{Y} 2) / 2$ \\
\hline Тубинский (станд.) & 37,2 & 37,5 & 42,9 & 39,20 & 40,05 \\
\hline Аргумент & 42,9 & 49,8 & 48,8 & 47,17 & 45,85 \\
\hline Голец & 29,1 & 27,7 & 30,6 & 29,13 & 29,85 \\
\hline Саян & 45,0 & 44,3 & 44,9 & 44,73 & 44,95 \\
\hline Сиг & 39,8 & 47,5 & 45,2 & 44,17 & 42,50 \\
\hline Урал 2 & 41,4 & 47,2 & 50,6 & 46,40 & 46,00 \\
\hline HСР $_{05 \text { А }}$ & & & & 10,67 & \\
\hline HСР $_{05}$ & & & & 7,55 & \\
\hline
\end{tabular}

Наибольшей стрессоустойчивостью (У2-У1) по урожайности зерна обладают сорта Голец, Саян, Сиг. Наиболее высокую и стабильную урожайность в различных условиях среды формируют сорта Тубинский, Аргумент и Саян. ИЭП был рассчитан по формуле

$$
\text { ИЭП }=\frac{\frac{\mathrm{yC} 1}{\mathrm{C} 01}+\frac{\mathrm{yC} 2}{\mathrm{C} 02}+\frac{\mathrm{yC} n}{\mathrm{Cy} 0 n}}{n},
$$

где УС - урожайность сорта; СУО - средняя урожайность всех сортов в опыте; 1, 2 и т.д. число опытов.

Коэффрициент вариации (V) - стандартное отклонение, выраженное к средней арифметической данной совокупности. Незначительная изменчивость урожайности (V) у сортов Саян и Сиг. Из остальных сортов только у сорта Урал 2 она превысила 20\%-й рубеж (табл. 3). 
Очень высокую отзывчивость на изменения условий выращивания в условиях интенсивной технологии показали сорта Тубинский и Аргумент. В противоположность им остальные сорта проявили себя как слабоотзывчивые. Такие сорта считаются наиболее адаптированными к изменениям условий выращивания благодаря тому, что bi у них меньше 1 [13]. В целом по урожайности в интенсивных условиях возделывания наиболее пластичными были сорта Аргумент, Саян, Сиг.

\section{Пластичность сортов ярового овса по урожайности}

\begin{tabular}{|l|c|c|c|c|}
\hline \multicolumn{1}{|c|}{ Сорт } & У2-У1 & ИЭП & V & bi \\
\hline Тубинский (станд.) & $-1,23$ & 1,138 & 18,813 & 3,289 \\
\hline Аргумент & $-0,70$ & 1,129 & 16,358 & 2,251 \\
\hline Голец & $-0,09$ & 0,807 & 17,525 & 0,811 \\
\hline Саян & 0,14 & 1,041 & 9,443 & $-0,730$ \\
\hline Сиг & $-0,01$ & 0,997 & 1,638 & $-0,047$ \\
\hline Урал 2 & $-0,56$ & 0,887 & 24,046 & 0,426 \\
\hline
\end{tabular}

ПУСС позволяет одновременно учитывать уровень и стабильность урожайности и характеризует способность отзываться на улучшение условий выращивания, а при их ухудшении поддерживать достаточно высокий уровень продуктивности. ПУСС вычисляется умножением средней урожайности сорта на индекс стабиль- ности (L'). Его, в свою очередь, рассчитывают делением средней урожайности сорта на коэффициент вариации (V). Чем выше ПУСС - тем стабильнее сорт. Наиболее стабильные урожаи, по данным L'(индекс стабильности), формировали Сиг, Саян и Аргумент (табл. 4).

\section{Стабильность сортов ярового овса по урожайности}

\begin{tabular}{|l|c|c|c|c|}
\hline \multicolumn{1}{|c|}{ Сорт } & $\mathrm{L}^{\prime}$ & ПУСC & $\mathrm{d}$ & S2d \\
\hline Тубинский (станд.) & 0,206 & 0,796 & 29,861 & 1,060 \\
\hline Аргумент & 0,234 & 0,897 & 28,217 & 0,785 \\
\hline Голец & 0,156 & 0,425 & 26,524 & 0,458 \\
\hline Саян & 0,371 & 1,300 & 16,755 & 0,219 \\
\hline Сиг & 2,054 & 6,908 & 2,655 & 0,006 \\
\hline Урал 2 & 0,125 & 0,373 & 39,071 & 1,038 \\
\hline
\end{tabular}

Они же проявили высокую способность формировать довольно высокие урожаи независимо от условий выращивания. Голец, Саян, а особенно Сиг, проявили себя как сорта, способные давать стабильные урожаи в различных условиях выращивания. У них же мера стабильности $\left(\mathrm{S}^{2} \mathrm{~d}\right)$ имеет наименьшую величину, что свидетельствует об их высокой приспособленности к ухудшению условий выращивания. Аргумент, Голец, Саян и Сиг показали общую способность формировать стабильно высокие урожаи (табл. 4).

Голец, Саян, Сиг показали наибольшую стрессоустойчивость по массе 1000 зерен. Бо- лее высокая экологическая пластичность была у сортов Аргумент, Саян, Урал 2, изменчивость массы 1000 зерен не превысила 10 \% у всех сортов, кроме Урала 2 (табл. 5). Соответственно, у овса масса 1000 зерен преимущественно имеет незначительную величину. Это отчасти подтверждают результаты исследований, проведенных на Канском государственном сортоиспытательном участке в 2008-2011, 2013-2016 гг., где данный показатель не превышал 11,1 \% в условиях экстенсивного земледелия [14]. 
Пластичность сортов ярового овса по массе 1000 зерен

\begin{tabular}{|l|c|c|c|c|}
\hline \multicolumn{1}{|c|}{ Сорт } & У2-У1 & ИЭП & V & bi \\
\hline Тубинский (станд.) & $-5,70$ & 0,938 & 8,183 & 1,068 \\
\hline Аргумент & $-5,90$ & 1,128 & 7,905 & 1,424 \\
\hline Голец & $-1,50$ & 0,698 & 4,978 & 0,209 \\
\hline Саян & 0,10 & 1,073 & 0,846 & $-0,052$ \\
\hline Сиг & $-5,40$ & 1,056 & 8,949 & 1,371 \\
\hline Урал 2 & $-9,20$ & 1,108 & 10,026 & 1,981 \\
\hline
\end{tabular}

Коэфффициент линейной регрессии сортов Тубинский, Аргумент, Сиг, Урал 2 позволяет сделать вывод: данные сорта способны формировать высокую массу 1000 зерен в лучших условиях и резко снижать ее в худших. Голец и Саян, наоборот, лучше приспособлены к ухудшению условий выращивания.
По массе 1000 зерен как наиболее пластичные себя показали сорта Аргумент, Голец и Саян.

По всем показателям стабильности вне конкуренции был Саян. По индексу стабильности остальные сорта показали приблизительно одинаковые результаты. По ПУСС несколько лучший результат среди остальных сортов показал Аргумент (табл. 6).

Таблица 6

\section{Стабильность сортов ярового овса по массе 1000 зерен}

\begin{tabular}{|l|c|c|c|c|}
\hline \multicolumn{1}{|c|}{ Сорт } & $\mathrm{L}^{\prime}$ & ПУСС & $\mathrm{d}$ & $\mathrm{S}^{2} \mathrm{~d}$ \\
\hline Тубинский (станд.) & 4,790 & 187,781 & 13,287 & 8,036 \\
\hline Аргумент & 5,966 & 281,414 & 13,855 & 5,479 \\
\hline Голец & 5,852 & 170,497 & 9,477 & 3,725 \\
\hline Саян & 52,855 & 2364,396 & 1,556 & 0,256 \\
\hline Сиг & 4,935 & 217,970 & 16,211 & 10,568 \\
\hline Урал 2 & 4,628 & 214,746 & 18,182 & 0,103 \\
\hline
\end{tabular}

Размах массы 1000 зерен, кроме Саяна, меньше $10 \%$ только у голозерного сорта Голец. У других сортов он существенно превышает 10\%-й уровень. Только по мере стабильности Саян уступил звание лучшего сорту Урал 2. У последнего фрактическая масса 1000 зерен меньше отличалась от теоретически возможной, чем у Саяна. S² показывает отклонение фактических показателей от теоретически возможных (рассчитываемых на основе средней величины сорта и индекса среды). Чем этот показатель ближе к нулю, тем отклонение фракта от теории меньше. По параметрам стабильности величины массы 1000 зерен Аргумент, Голец, Саян показали лучший результат. Это говорит о том, что они могут формировать крупную массу 1000 зерен стабильно в любых условиях. Особенно это касается Саяна.

Выводы. Выявлены наиболее пластичные и стабильные сорта ярового овса в Красноярской лесостепи при возделывании их по интенсивной технологии:
1) наиболее пластичными по урожайности зерна сортами ярового овса являются Аргумент, Саян, Сиг. К самым пластичным сортам ярового овса по массе 1000 зерен относятся Аргумент, Голец, Саян;

2) стабильно формируют высокую урожайность и массу 1000 зерен сорта ярового овса Аргумент, Голец и Саян.

\section{Литература}

1. Сокол Т.В., Петренкова В.П., Кобизева Л.Н. Екологічна пластичність та стабільність зразкі в генофонду гороху застій кістю до хвороб та шкідників // Селекція і насінництво. 2012. Вип. 101. С. 20-29.

2. Bradshaw A.D. Evolutionary significance of phenotypic plasticity in plants // Advances in Genetics. 1965. Vol. 13. P. 115-155.

3. Прянишников Д.Н., Якушкин И.В. Растения полевой культуры (частное земледелие). М. : Сельхозгиз, 1936. 844 с. 
4. Байкалова Л.П., Долгова О.А. Корреляционная зависимость содержания белка в зерне овса различных сортов от биологических особенностей и экологических факторов в Красноярском крае // Кормопроизводство. 2018. № 8. С. 30-34.

5. Федин М.А. Методика государственного сортоиспытания сельскохозяйственных культур. Общая часть. Вып. 1. М., 1985. 269 с.

6. Eberhart S.A., Russell W.A. Stability parameters for comparing varieties // J. Crop. Sci. 1966. V. 6. № 1. P. 36-40.

7. Rossielle A.A., Hamblin J.B. Theoretical aspects selection for yield in stress and nonstress environments // Crop Science. 1981. № 6. P. 21.

8. Грязнов А.А. Селекция ячменя в Северном Казахстане // Селекция и семеноводство. 2000. № 4. C. 2-8.

9. Неттевич Э.Д., Моргунов А.И., Максименко М.И. Повышение эффективности отбора яровой пшеницы на стабильность урожайности и качества зерна // Вестник с.-х. науки. 1985. № 1. С. 66-73.

10. Доспехов Б.А. Методика полевого опыта. М.: Колос, 1985. $351 \mathrm{c}$.

11. Зыкин В.А., Мешков В.В., Сапега В.А. Параметры экологической пластичности сельскохозяйственных растений, их расчет и анализ: метод. рекомендации. Новосибирск : Сиб. отд-ие ВАСХНИЛ, 1984. С. 1-24.

12. Селянинов Г.Т. О сельскохозяйственной оценке климата // Труды о сельскохозяйственной метеорологии. 1928. Вып. 20. C. $169-178$.

13. Сапега В.А., Турсумбекова Г.Ш. Урожайность среднеспелых сортов яровой пшеницы и параметры их адаптивности в различных природно-климатических зонах Северного Зауралья // Успехи современного естествознания. 2016. № 11. С. 65-69.

14. Байкалова Л.П., Серебренников Ю.И. Голозерный ячмень и овес в Сибири. Красноярск : Изд-во КрасГАУ, 2018. 298 с.

\section{Literatura}

1. Sokol T.V., Petrenkova V.P., Kobizeva L.N. Ekologichna plastichnist' ta stabil'nist' zrazki v genofondu gorohu zastij kistju do hvorob ta shkidnikiv // Selekcija i nasinnictvo. 2012. Vip. 101. S. 20-29.

2. Bradshaw A.D. Evolutionary significance of phenotypic plasticity in plants // Advances in Genetics. 1965. Vol. 13. P. 115-155.

3. Prjanishnikov D.N., Jakushkin I.V. Rastenija polevoj kul'tury (chastnoe zemledelie). M.: Sel'hozgiz, 1936. $844 \mathrm{~s}$.

4. Bajkalova L.P., Dolgova O.A. Korreljacionnaja zavisimost' soderzhanija belka v zerne ovsa razlichnyh sortov ot biologicheskih osobennostej i jekologicheskih faktorov $v$ Krasnojarskom krae // Kormoproizvodstvo. 2018. № 8. S. 30-34.

5. Fedin M.A. Metodika gosudarstvennogo sortoispytanija sel'skohozjajstvennyh kul'tur. Obshhaja chast'. Vyp. 1. M., 1985. 269 s.

6. Eberhart S.A., Russell W.A. Stability parameters for comparing varieties // J. Crop. Sci. 1966. V. 6. № 1. P. 36-40.

7. Rossielle A.A., Hamblin J.V. Theoretical aspects selection for yield in stress and nonstress environments // Crop Science. 1981. № 6. P. 21.

8. Grjaznov A.A. Selekcija jachmenja v Severnom Kazahstane /I Selekcija i semenovodstvo. 2000. № 4. S. 2-8.

9. Nettevich Je.D., Morgunov A.I., Maksimenko M.I. Povyshenie jeffektivnosti otbora jarovoj pshenicy na stabil'nost' urozhajnosti i kachestva zerna // Vestnik s.-h. nauki. 1985. № 1. S. 66-73.

10. Dospehov B.A. Metodika polevogo opyta. M.: Kolos, 1985. $351 \mathrm{~s}$.

11. Zykin V.A., Meshkov V.V., Sapega V.A. Parametry jekologicheskoj plastichnosti sel'skohozjajstvennyh rastenij, ih raschet i analiz: metod. rekomendacii. Novosibirsk: Sib. otd-ie VASHNIL, 1984. S. 1-24.

12. Seljaninov G.T. O sel'skohozjajstvennoj ocenke klimata // Trudy o sel'skohozjajstvennoj meteorologii. 1928. Vyp. 20. S. 169-178.

13. Sapega V.A., Tursumbekova G.Sh. Urozhajnost' srednespelyh sortov jarovoj pshenicy i parametry in adaptivnosti $\mathrm{V}$ razlichnyh prirodno-klimaticheskih zonah Severnogo Zaural'ja // Uspehi sovremennogo estestvoznanija. 2016. № 11. S. 65-69.

14. Bajkalova L.P., Serebrennikov Ju.I. Golozernyj jachmen' i oves v Sibiri. Krasnojarsk: Izd-vo KrasGAU, 2018. 298 s. 